\title{
FAILED PREHOSPITAL FIBRINOLYSIS IN PATIENT WITH PERCUTANEOUS CORONARY INTERVENTION IN ST-ELEVATION MYOCARDIAL INFARCTION
}

\author{
Makharynska O. S. ${ }^{I}$, Oktiabrova I. I. ${ }^{1}$, Kartvelishviliy H. Yu. ${ }^{2}$, Okhryamkina O. O. ${ }^{2}$ \\ ${ }^{1}$ V. N. Karazin Kharkiv National University, Kharkiv, Ukraine \\ ${ }^{2}$ Kharkiv Railway Clinical Hospital No. 1 of Brenche of «HC» JSC «Ukrzaliznytsia», Kharkiv, Ukraine
}

On the example of the clinical case of newly diagnosed ST-elevation myocardial infarction combination of different reperfution strategies and their benefit was discussed. Recommendations on lifestyle modification and medicament treatment tactics are described.

KEY WORDS: STEMI, thrombolysis, effective treatment, coronarography

\section{НЕЕФЕКТИВНИЙ ДОГОСПІТАЛЬНИЙ ФІБРИНОЛІЗИС У ПАЦИСНТА 3 ЧРЕЗШКІРНОЮ КОРОНАРНОЮ ІНТЕРВЕНЦІЕЮ У ВИПАДКУ ІНФАРКТУ МІОКАРДА 3 ЕЛЕВАЦІЕЮ ST-СЕГМЕНТУ}

\author{
Махаринська О. С. ${ }^{1}$, Октябрьова I. I. ${ }^{1}$, Картвелішвілі А. Ю. ${ }^{2}$, Охрямкіна О. О. ${ }^{2}$ \\ ${ }^{1}$ Харківський національний університет імені В. Н. Каразіна, м. Харків, Україна \\ ${ }^{2}$ ХКЛ ЗТ № 1 Філії «ЦОЗ» ПАТ «Укрзалізниця», м. Харків, Україна
}

На прикладі клінічного випадку вперше виявленого інфаркту міокарда 3 елевацією ST-сегменту було розглянуто комбіновану реперфузію за допомогою різних методик і обговорено іiі переваги. Описано рекомендації з модифікації способу життя, а також тактику медикаментозного лікування.

КЛЮЧОВІ СЛОВА: STEMI, тромболізис, ефективне лікування, коронарографія

\author{
НЕЭФФЕКТИВНЫЙ ДОГОСПИТАЛЬНЫЙ ФИБРИНОЛИЗИС \\ У ПАЦИЕНТА С ЧРЕЗКОЖНОЙ КОРОНАРНОЙ ИНТЕРВЕНЦИЕЙ \\ В СЛУЧАЕ ИНФАРКТА МИОКАРДА С ЭЛЕВАЦИЕЙ ST-СЕГМЕНТА
}

Махаринская Е. С. ${ }^{1}$, Октябрева И. И. ${ }^{1}$, Картвелишвили А. Ю. ${ }^{2}$, Охрямкина Е. А. ${ }^{2}$

${ }^{1}$ Харьковский национальный университет имени В. Н. Каразина, г. Харьков, Украина

${ }^{2}$ ХКБ ЖДТ № 1 Филиала «ЦЗ» ПАО «Укрзализныця», г. Харьков, Украина

На примере клинического случая впервые выявленного инфаркта миокарда с элевацией ST-сегмента была рассмотрена комбинированная реперфузия с помощью различных методик и обсуждены ее преимущества. Описаны рекомендации по модификации образа жизни, а также тактика медикаментозного лечения.

КЛЮЧЕВЫЕ СЛОВА: STEMI, тромболизис, эффективное лечение, коронарография

\section{INTRODUCTION}

Ischaemic heart disease accounts for almost 1.8 million annual deaths in the world and around $20 \%$ of all deaths in Europe, the STelevation myocardial infarction (STEMI) incidence rate ranged from 43 to 144 per 100000 per year in different European countries [1]. Primary percutaneous coronary intervention (PPCI) is preferred for most patients if it can be performed with less than a
90 minute delay from the point of first medical contact. However, fibrinolysis (FL) remains an important therapeutic modality, due to limited availability of PPCI. Primary failure of fibrinolysis manifested clinically as persistent or worsening chest pain or/and ST segment elevation, hemodynamic instability or heart failure [2]. Meta-analysis of randomized controlled trials maden by Vincent Roule et others [3] showed that compared with PPCI, prehospital fibrinolysis in the early period 
associated with better prognosis, included similar mortality rates, lower rates of cardiogenic shock, and higher rates of stroke in patients with ST-segment elevation myocardial infarction (STEMI). Despite the fact that the number of studies compared were relatively low, results supported an hypotise that prehospital FL with transfer to percutaneous coronary intervention (PCI) centers is a valid alternative to PPCI, which allows potential limitation of resources allocated to developing proximity 24/7 PCI facilities [4]. The benefit of PPCI over prehospital FL is not clear among patients managed early in the prehospital setting, but both of them are time-dependent with similar rates of mortality [3].

\section{CLINICAL CASE}

A 62-year old man was admitted by ambulance in the emergency department (ED) of Kharkiv Railway Clinical Hospital No. 1 with complains on periodical pressing pain in the heart without irradiation, general weakness, discomfort in the chest.

\section{ANAMNESIS MORBI}

06-sept-2017 in 3p.m. after intensive physical exertion he felt extremely bad, appeared intense pressing pain behind sternum with irradiation to the right hand, nitroglycerin tablet sublingual didn't help, ambulance made ECG and patient was delivered to local hospital with diagnosis STEMI, where was done thrombolysis with recombinant plasmin activator tenecteplase, prescribed morphine, nitroglycerin and heparin. As there is no possibility to transfer patient in appropriate timelines from Krasnograd to Kharkiv for primary percutaneous coronary intervention, was decided to make fibrinolysis with further PCI if needed. After slight improvement of patient state, patient was referred for specific treatment in the cardiological department of Kharkiv Railway Clinical Hospital No. 1. From 2007 - he has history of Arterial Hypertension (AH) with blood pressure (BP) levels 170190/100 mm Hg, patient took medications only from time to time. According to patients statement, in the summer 2017 he had transient ischemic attack (TIA) (with symptoms as numbness of the right arm, rigidity of the mouth right angle), which resolved itself without any treatment. Patient has cardio-vascular risk factors in family history: mother of patient had stroke.

\section{ANAMNESIS VITAE}

Childhood infections, injuries, sexually transmitted diseases were denied by patient. Bone tuberculosis in the childhood with necroectomy and hip joint defect plastic. Hereditary diseases are not identified. Allergic history is not burdened. Smoking - denied, not alcohol abuser.

\section{OBJECTIVE EXAMINATION}

Conciseness - clear, state - severe, body position - active. Patient is orientated in place, time, his personality. Pale skin and mucosae, lips cyanosis. Thyroid: no pathological changes. Musculoskeletal system - left hip shortened after operation on around $10 \mathrm{~cm}$. Breath rate 22-24/min. Lung percussion: no clinically significant changes. Lung auscultation: vesicular breathing. Borders of the heart: left border - outside of midclavicular left line on $1.5 \mathrm{~cm}$, others - within normal parameters. Heart auscultation: rhythmic, heart tones muffled. Pulse - rhythmic, 90 bts/min. BP 150/80 mm Hg. Abdomen: normal size, symmetric, unpainful. Liver: liver margin near the rib cage, soft, no pain during palpation in right hypochondria. Spleen: normal. Pasternatsky symptom - negative from both sides. Edemas: not present.

In ED, preliminary diagnosis was: Coronary Arteries Disease: circular STEMI (06-oct2017). Trombolysis with tenecteplase. Arterial hypertension III stage, II degree, very high risk. Heart failure by Killip I stage.

\section{LABORATORY AND INSTRUMENTAL TESTS}

Complete Blood Count from 06-oct-2017: elevation of platelets $348 * 10^{9} / 1$ (N 180-320), all other parameters within normal limits.

Urinalysis: all parameters within normal limits.

In biochemistry analysis data significant were: abnormal level of Troponin I $1,92 \mathrm{mkg} / \mathrm{l}(\mathrm{N}<0,01)$, constant elevation of CFK-MB and CFK-NAC concentrations from admition time till coronarography / PCI (6-oct 2017 at 7p.m. - 13,8 u/l, 7-oct-2017 at 7a.m. $64,6 \mathrm{u} / \mathrm{l}$, at 1p.m. $-70,9 \mathrm{u} / \mathrm{l}$ respectively).

ECG during admition showed classical STEMI ECG changes as pathological ST segment elevation in II, III, V1-V6 leads with $\mathrm{T}$-wave inversion in lead, presence of $\mathrm{Q}$ wave $>3 \mathrm{~mm}$ only in aVR, IIId leads, ST - 
depression in aVL, sinus rhythm, heart rate $88 \mathrm{bts} / \mathrm{min}$, which was the confirmation of failed pre-hospital fibrinolysis.

In our patient Chest X-ray data was enlargement of heart shadow to the left, aorta without specific changes but enlarged mediastinum seen.

Because of elevation of serum cardiac enzymes levels, progression of ECG STEMI picture and presence of pain syndrome despite FL, coronary angiography was performed: Left type of coronary blood circulation. Diffuse atherosclerotic changes of vascular system. Left coronary artery: truncus - no specific changes, anterior descendant artery - stenosis $60 \%$ in proximal segment, tandem stenosis $80 \%$ in the middle segment, subocclusion in distal segment, intermedial artery $-80 \%$ stenosis, left circumflex artery $-70 \%$ stenosis (atherosclerotic plaque with instability signs). Right coronary artery: hypoplastic, area with atherosclerotic narrowing and occlusion $100 \%$ before marginal brach (TIMI-0 - no antegrade flow beyond the point of occlusion).

For the occlusion in right coronary artery was done PCI with stent «Integriti (BMS)» $2,5 * 26 \mathrm{~mm}$. Blood flow after stenting TIMI-3 (normal flow with complete filling of the distal territory).

Echocardiography after coronary angiography was maden: aorta with sclerotic wall changes, $d-33,9(\mathrm{~N}-20-37)$. Ascending aorta $-\mathrm{d}-39,3(20-37 \mathrm{~mm})$. Aortic regurgitation II stage. Tricuspid valve - regurgitation I stage. Pulmonary trunk valve - N. Pressure in pulmonary trunk is $21,7 \mathrm{~mm} \mathrm{Hg}(<15)$. Mitral valve - regurgitation I stage. $\mathrm{EF}-52 \%(\mathrm{~N}-$ 55-78 \%). FS - $27 \%(\mathrm{~N}-28-44 \%)$. Hypokinesia of apex segment, upper part of intraventricular septum and posterior-diaphragmal wall of LV myocardium.

Left Ventricle: FDD - 48,5 mm ( $\mathrm{N}-35-$ $55 \mathrm{~mm})$, FSD - 35,6 mm ( $-23-38 \mathrm{~mm})$, posterior wall thickness $-14,9 \mathrm{~mm}(\mathrm{~N}-6-$ $13 \mathrm{~mm})$. Intraventricular septum size 14,4 mm ( 6-11 mm) - enlarged.

Right Ventricle: Diameter - 25,2 mm (N 9-20 mm), wall thickness - 6,0 $\mathrm{mm}(\mathrm{N}-3-$ $6 \mathrm{~mm})$. Left atrium - not enlarged $-33,5 \mathrm{~mm}$ in diameter ( $\mathrm{N}-$ till $38 \mathrm{~mm}$ ). Right atrium - not enlarged $-35,6 \mathrm{~mm}$ in diameter $(\mathrm{N}-25-37)$. Interatrial septum - not changed. Valvular apparatus is not changed, except tricuspid valve - regurgitation I degree. Conclusion: Aortic atherosclerosis, valvular system of aortic and mitral valves. Dilation of ascending part of aorta, aortic regurgitation II stage. Hypertrophy of the left ventricle myocardium by concentric type. Hypokinesia of apex segment, upper part of intraventricular septum and posteriordiaphragmal wall of LV myocardium. Decreased pump function and increased diastolic rigidity of left ventricle myocardium. Pulmonary hypertension I degree.

In 2017 ESC Guidelines for the management of acute myocardial infarction in patients presenting with ST-segment elevation, reperfusion therapy is recommended for all patients with symptoms of ischemia of $\leq 12$ hours duration and persistent ST-elevation. In this case patients should be transferred to a PCI-capable facility as soon as possible after bolus of lytics administration [1]. For patients presenting in a non-PCI centre, door-in to doorout time, defined as the duration between arrival of the patient at the hospital to discharge of the patient in an ambulance en route to the PCI centre, is a new clinical performance measure, and $\leq 30 \mathrm{~min}$ is recommended to expedite reperfusion care [5]. In cases similar to our patient case when initial fibrinolytic treatment is failed (ST-segment resolution < $50 \%$ within $60-90 \mathrm{~min}$ of fibrinolytic administration) with manifestation as chest pain, further elevation serum concentrations of main cardiac biomarkers should be performed an emergent PCI [1]. The key issue is the optimal time delay between successful lysis and PCI. Different strategies were observed: from a median of $1.3 \mathrm{~h}$ in the Combined Angioplasty and Pharmacological Intervention versus Thrombolytics ALone in Acute Myocardial Infarction (CAPITAL AMI) trial to $17 \mathrm{~h}$ in the Grupo de Analisis de la Cardiopatia Isque'mica Aguda (GRACIA)-1234 and STREAM trials [6]. Based on this analysis, in case of successful fibrinolysis routine coronary angiography PCI was recommended to perform in timelines from 2 to 24 hours, as it was done in our clinic.

After coronarography and PCI with stent application ECG showed sinus rhythm, negative T-waves in III, aVL, V1; heart rate $85 \mathrm{bts} / \mathrm{min}$.

Holter 24-monitoring performed after PCI showed: sinus rhythm with HR variability from 52 to 91 bts in min with registered solitary supraventricular premature contractions (223 in total), paired supraventricular premature contractions (30 in total), episodes of atrial rhythm with duration of 8 complexes with HR 
80 bts in min, no ST-segment elevation or depression episodes.

\section{FINAL DIAGNOSIS}

Acute Coronary Syndrome: circular STEMI (06-oct-2017). Trombolysis with tenecteplase (06-oct-2017). Coronary arteries atherosclerosis (coronary angiography 06-oct-2017) with PCI performed (right coronary artery stenting 06-oct-2017). Arterial hypertension III stage, II degree, very high risk. Heart failure by Killip I stage.

\section{TREATMENT RECEIVED IN HOSPITAL}

Clopidogrel 75 mg 1 time/day, aspirin 100 mg 1 time/day morning, eplerinone $25 \mathrm{mg} 1$ time/day, metoprolol $25 \mathrm{mg} 2$ times/day, enoxaparinum natrium $0,8 \mathrm{ml}(80 \mathrm{mg}) 2$ times a day subcutaneously, pantoprazole $40 \mathrm{mg} 2$ times a day, atorvastatin $80 \mathrm{ml} 1$ time/day.

\section{RECOMMENDATIONS}

According to 2017 ESC Guidelines for the management of acute myocardial infarction in patients presenting with ST-segment elevation [1], the following recommendations may be applicable for our patient after discharge from hospital and for prevention of further STEMI episodes:

1. A reduction in chest pain after nitroglycerin administration is not recommended as a diagnostic manoeuvre in patient with suspected STEMI because of misleading results.

2. Early ambulation (day 1) is recommended in the majority of patients especially after using the radial access for PCI and low risk patients by PAMI-II criterias (age less than 70 years, left ventricle ejection fraction (LVEF) more than $45 \%$, one- or two-vessel disease, successful PCI, and no persistent arrhythmias). But for patients with extensive myocardial damage (as our patient is), heart failure, hypotension, or arrhythmias should be advised a prolongation of hospital stay.

3. Early echocardiography with LVEF assessment is indicated in all patients and it was done in our case. Medical therapy should include dual antiplatelet therapy (DAPT), anticoagulation, and secondary prevention therapies. DAPT, combining aspirin with lowdose (75-100 mg) and a P2Y12 inhibitor (clopidogrel is co-adjuvant of choice after fibrinolysis) is recommended for 12 months. In STEMI patients with stent implantation and an indication for oral anticoagulation, triple therapy should be considered for 1-6 months. The use of ticagrelor or prasugrel is not recommended as part of triple antithrombotic therapy with aspirin and oral anticoagulation.

4. Secondary prevention: our patient is not obese, don't smoke and not an alchohol abuser but for STEMI patient is important to take part in an exercise-based cardiac rehabilitation programme which includes exercise training, risk factor modification, education, stress management, and psychological support.

5. As one of most important risk factors in patients with STEMI, high blood pressure, along with reduced salt intake, increased physical activity, should be pharmacologically controlled with a systolic blood pressure targets of $<120 \mathrm{~mm} \mathrm{Hg}$ in patients at very high risk as our patient is.

In hemodynamically stable patients undergoing fibrinolysis oral beta-blocker initiation should be considered within the first $24 \mathrm{~h}$. Lipid-lowering treatment should be started as early as possible, lipids profile advised being re-evaluated in 4-6 weeks after the ACS to determine whether the target levels have been reached and regarding safety issues. Routine use of calcium antagonists and nitrates in the acute phase is not indicated and showed no benefits. Treatment with ACE inhibitors was recommended in all STEMI patients with systolic LV dysfunction or heart failure, hypertension, or diabetes.

\section{CONCLUSIONS}

From one hand, in spite of side-effects of treatment as an increased risk of stroke and hemorrhagic stroke, prehospital FL is associated with a decreased risk of cardiogenic shock and its effectiveness depends on the time from symptom onset to reperfusion. From other hand, despite the fact that PPCI is the recommended default reperfusion strategy, its effectiveness depends also on time limits and absence of the majority of PPCI-facilated hospitals worldwide. Combination of prehospital single-bolus FL following after 3$24 \mathrm{~h}$ early routine angiography and PCI can improve post-STEMI survival and help to avoid hyperreactivity and thrombin-induced platelet activation after FL, which can be a key to success in effective treatment and rehabilitation after STEMI in patients without high risk factors of potential bleeding or stroke. 


\section{REFERENCES}

1. 2017 ESC Guidelines for the management of acute myocardial infarction in patients presenting with STsegment elevation / [B. Ibanez, S. James, S. Agewall, et al.] // European Heart Journal. - 2017. - No. 00. p. $1-66$.

2. Sutton A.G. A randomized trial of rescue angioplasty versus a conservative approach for failed fibrinolysis in ST-segment elevation myocardial infarction: the Middlesbrough Early Revascularization to Limit INfarction (MERLIN) trial. / [A. G. Sutton, P. G. Campbell, R. Graham, et al.] // J Am Coll Cardiol. - 2004. - No. 44 (2). - p. 287.

3. Roule V. Prehospital fibrinolysis versus primary percutaneous coronary intervention in ST-elevation myocardial infarction: a systematic review and meta-analysis of randomized controlled trials / [V. Roule, P. Ardouin, K. Blanchar, et al.] // Critical Care. - 2016. - No. 20. - p.359.

4. Jordan M. Improving door-to-needle times for patients presenting with ST-elevation myocardial infarction at a rural district general hospital / M. Jordan, J. Caesar // BMJ Quality Improvement Reports. - 2016. No. 5. - p. 1-10.

5. Wang T. Y. Association of door-in to door-out time with reperfusion delays and outcomes among patients transferred for primary percutaneous coronary intervention. / [T. Y. Wang, B. K. Nallamothu, H. M. Krumholz, et al.]. // JAMA. - 2011. - No. 305 (24). - p. 2540-2547.

6. Madan M. Relationship between time to invasive assessment and clinical outcomes of patients undergoing an early invasive strategy after fibrinolysis for ST-segment elevation myocardial infarction: a patient-level analysis of the randomized early routine invasive clinical trials. / [M. Madan, S. Halvorsen, C. Di Mario, et al.]. JACC Cardiovasc Interv. - 2015. - No. 8. - p. 166-174. 